\title{
Computer teaching process optimization strategy analysis of thinking ability
}

\author{
Liang LUO \\ ChongQing City Management College, China Chongqing401331
}

\begin{abstract}
As is known to all, computer is a college student in a university course, one of the basic course in the process of education for college students which lay a theoretical foundation for the next professional learning. At the same time, in recent years, countries and universities attach great importance to and focus on computer teaching for young college students, the purpose is to improve students' thinking ability, eventually to promote college students' ability to use computational thinking to solve and analyze the problems of daily life. Therefore, this article on how to the calculation of optimization in the process of computer teaching college students thinking ability on further discussion and analysis, and then explore the strategies and methods, so as to promote the computer teaching in the process of the cultivation of thinking ability and optimize the computer.
\end{abstract}

Key Word.Computational thinking; Computer teaching; Ability training; Implementation strategy

\section{Basic computer thinking is introduced}

\subsection{Basic connotation}

When it comes to computing thinking, academic scholars and experts are given a variety of views and opinions. In 2006, for example: the head of the department of computer science at Carnegie Mellon university weeks to really (Jeannette m. Wing) professor put forward its views, can be roughly summed up as the computer is a computer technology to solve problems through thinking, at the same time with the computer deeper levels of related thinking activity, the essence of which is the abstraction and automation. This view shows and puts forward the computer thinking is a must have for the masses, the essence of thinking mode, it is indispensable to People's Daily life and study. All in all, for a variety of different views and opinions, though there are differences, but take its generality, namely computer thinking is nothing but a kind of scientific and practical thinking, in People's Daily study and work plays an important role.

\subsection{Current situation of the development of}

As is known to all, computer courses generally opened in college students of the first semester of school, to improve college students' knowledge and understanding of computer basic knowledge and theory, so as to lay a foundation for the professional course learning. On the one hand, the development of the computer teaching to a certain extent, improve the college students a basic understanding of computer technology; But, on the other hand, college students' understanding of computer technology in the foundation stage, only failed to fundamentally understand the working principle of the computer technology, let alone the cultivation of 
thinking ability and optimize the calculation. Aiming at the existing problems and the insufficiency of computational thinking ability, can be roughly classified into the following several aspects.

\subsubsection{Heavy practical, Theory of light}

Combined with students' daily learning, can learn the current college students in the learning process exists the phenomenon of "practical, light theory". That is to say, in the process of computer courses, there are only takes the computer technology, ignore the phenomenon of computer theory. To this end, the school internal education workers should pay attention to the teaching of computer theory and computer thinking, so as to improve and optimize the calculation of students thinking ability.

\subsubsection{Unconscious thinking teaching}

Because the computer thinking in China's development time is shorter, enough attention in the internal teaching in colleges and universities, on the other hand is due to the essence of the computer technology in order to solve the problem, so in general, within the general computer educators in colleges and universities in the unconscious of computer teaching. Therefore, for this problem, the computer education in colleges and universities practitioners should focus on awareness of computer course teaching, so as to improve computing the existence and the importance of thinking ability.

\subsubsection{Not from strategic level to realize computer thinking on the importance of the cultivation of talents}

At this stage for computer thinking there are incomplete and lack of the understanding of the place, just think it is a part of computer theory, but not from the overall and strategic level to realize calculation thinking instead of other aspects below. Future, therefore, in the process of optimization calculation thinking ability, want to notice from the overall and strategic level general calculation combined with computer teaching of thinking, so as to promote the computer teaching strategy.

\section{The need for analysis}

From the previous illustration and analysis can know, in the internal to develop computer education in colleges and universities, on the one hand is to college students in the future to better learn professional class foundation, on the other hand through the computer teaching, and improve college students' thinking ability, enhancing the comprehensive quality of ascension, the finally adapt to the development of today's information age. In particular, on the one hand, improve the students' computer skills, help it to better solve the problems and deal with; , on the other hand, improve the students' judgment ability in information, namely in the current rapid development of computer technology, while the use of science and technology brought great convenience to our daily life, but the technology is a double-edged sword, it will also bring challenges to our life, therefore, the cultivation of thinking ability by calculation and optimization, can fundamentally improve the cognitive ability of information technology, to form his own judgment. Finally, calculation of thinking and ability can promote college students on their cognitive ability. Due to the thinking mode of thinking is a kind of scientific calculation, so college students after the formation of computational thinking can improve on their cognitive abilities.

\section{Computational thinking ability training strategy and approach}

To sum up, at this stage in the process of enhancing the teaching of computer calculation of the cultivation of thinking ability, is very necessary. Therefore, the author will for optimization strategy and way of thinking ability, can be summarized as the following respects.

\subsection{The teaching mode and teaching method reform}

In terms of the traditional computer teaching mode and method, its basic in computing 
thinking ability is introduced. Specifically, under the traditional teaching mode and methods, calculation of thinking ability is mainly intangible cover with the other abilities, such as: innovation ability, application ability, eventually led to the thinking ability is the unconscious. Therefore, in order to improve the present situation, colleges and universities and teaching patterns and methods to reform. Mainly embodied in: on the one hand, calculates the thinking ability of the unconscious teaching into teaching consciousness, namely the clear will calculate the cultivation of thinking ability is put forward to teaching, so as to calculate the existence and importance of thinking ability; , on the other hand, change teaching mode, the practical technology to be teaching mode by the previous teaching mode into teaching model of cultivating the ability of thinking and. In addition, still should strengthen the reform of teaching method, which USES the category and professional teaching method. In other words, the computer teaching of the college students according to the professional category for professional education, to better promote students' thinking ability.

\subsection{Expand the extracurricular teaching, encourage students to participate in science class competition}

First, by expanding the extracurricular teaching, on the one hand, can enrich student's study life, to a certain extent, make up for the deficiency of the classroom teaching; On the other hand, expand the extracurricular education, can widen students' view. Second, the discipline competition is the present college students show their professional skills and talents of the important carrier, through the discipline competition, to some extent, stimulate students' initiative and enthusiasm, eventually to improve the calculation for the cultivation of thinking and ability. At the same time, through the discipline of competition can promote study and communication between college students, help to calculate the cultivation of thinking ability.

\subsection{Insist on computational thinking as the core concept, improve the basic teaching curriculum system}

In recent years, the state attaches great importance to the construction of the college computer teaching course, at the same time, the ministry of education will also be set for the college computer curriculum reform project. In addition, some colleges and universities to calculate thinking as the core, improve the basic teaching course system, to improve and optimize the effect of college students' thinking and ability, mainly reflects in: on the one hand, some colleges and universities with its actual situation and the student's basic qualities, compiled computer teaching material has its own characteristics, to a certain extent, it reflected the color according to their aptitude; Education, on the other hand, practitioners, also want to combine their own years of experience in education, through their understanding of the present college students thinking ability level, to actively explore suitable for college students' thinking ability training calculation and optimization of ways and methods, to enhance and optimize the computing thinking ability in the process of computer teaching. Anyhow, in any country or university itself, it should pay attention to the optimization of computer basic teaching curriculum system, to some extent, this is the key link of improving the computational thinking ability of university students and part.

\section{$3.4 \mathrm{We}$ will improve the mechanism of teaching evaluation}

As is known to all, the way of teaching evaluation is mainly the test, in order to achieve the purpose of evaluating students' mastery of knowledge level. In terms of the current examination system of the computer courses, the mainly through "written examination + machine try" mode for appraisal, can to some extent this evaluation to students mastering knowledge of computer theory and practice, but not the 
assessment to the students thinking ability. Therefore, colleges and universities should be in the present teaching evaluation mechanism, on the basis of the perfect for computing the examination link of thinking ability. Based on the improvement of the teaching evaluation system, to achieve the optimization calculation in computer teaching thinking ability, eventually to promote college students calculate their thinking skills.

\section{Conclusion}

Society played a great role in promoting. Computer technology in the calculation, on the other hand, the cultivation of thinking ability and improve requirements in the process of computer teaching should pay attention to the optimization calculation for college students thinking, so that every college students comprehensive quality accords with the demands of the development of human society. For this, big to small countries and universities, to each one education practitioners, to pay close attention to the quality education of college students, fundamentally improve college students' thinking ability calculation, prompting its computing thinking ability perfect fusion to social development and individual life.

\section{References}

[1] when yao, soubo ni, xue-dong zhang. The teaching of computer basic computational thinking training methods of research and discussion $[\mathrm{J}]$. Journal of agricultural network information, 2015 (03) : 108-110.

[2] druid, lan-shun nie. Computer curriculum reform the basic idea of computational thinking and university $[\mathrm{J}]$. Journal of China university teaching, 2013 (02) : 56-60.

[3] wang zhiqiang, fang-fang liu. Based on the computational thinking of reform of computer basic course study [J]. Journal of China university teaching, 2013 (6) : 59-60 + 36.

[4] druid, wang hao. University computer courses teaching content system for computing thinking $[\mathrm{J}]$. Journal of China university teaching, 2014 (7) : 59-66.

[5] Zhu Minghua Zhao Mingwei, each, hong-fei Lin. Discusses the computational thinking ability training in computer basic teaching [J]. Journal of China university teaching, 2012 (3) : 33-35.

TongQi [6] guo-xing peng, liu, Zhu Yanhui, Chen Fangqin. Around computational thinking in university computer foundation course teaching content optimization [J]. Journal of business and the development of science and technology, 2012 (01) : 62-64.

[7] Gong Pei once, Yang. Computational thinking training in university computer foundation teaching $[\mathrm{J}]$. Journal of China university teaching, 2012 (05) : 51-54.

[8] ZhanTao Deng Lei, zhi-gang liao. University computer foundation teaching for computing thinking culture $[\mathrm{J}]$. Journal of computer education, 2014 (05) : 1-4.

[9] YiMingJing, unpaid. Computational thinking ability training as the core of university computer $[\mathrm{J}]$. Journal of curriculum reform of computer education, 2014 (05) : 5-9. 